\title{
Evaluation of the Relationship between Serum 25-Hydroxyvitamin D Levels and Pulmonary Functions in Adult Asthma
}

\author{
Serum 25-Hidroksivitamin D Düzeylerinin Yetişkin Astım Hastalarında Pulmoner Fonksiyonlar ile \\ İlişkisinin Değerlendirilmesi
}

\author{
Olgun KESKİN ${ }^{1}$ \\ (D) 0000-0002-0995-7680 \\ Nilgün SEREMET KÜRKL ̈̈${ }^{2}$ \\ (D) 0000-0003-1394-0037
}

\begin{abstract}
${ }^{1}$ Antalya Training and Research Hospital Chest Diseases Clinic, Antalya, Turkey
\end{abstract}

${ }^{2}$ Akdeniz University Faculty of Health Sciences Department of Nutrition and Dietetics, Antalya, Turkey

\section{Corresponding Author Sorumlu Yazar \\ Nilgün SEREMET KÜRKLÜ}

nseremetkurklu@akdeniz.edu.tr

Received / Geliş Tarihi : 06.08.2020 Accepted / Kabul Tarihi : 16.11.2020 Available Online /

Çevrimiçi Yayın Tarihi : 25.12.2020

\begin{abstract}
Aim: This study was aimed to determine the relationship between serum 25-hydroxyvitamin $\mathrm{D}[25(\mathrm{OH}) \mathrm{D}]$ levels and the pulmonary functions in adult asthma patients.

Material and Methods: A total of 131 asthmatic patients' general characteristics, asthma symptoms, pulmonary function test, asthma control test (ACT) scores, serum 25(OH)D levels, body weight, and height were recorded. Body mass indexes (BMIs) of the patients were calculated and World Health Organization criteria were used for the classification. Patients with serum $25(\mathrm{OH}) \mathrm{D}$ levels below $20 \mathrm{ng} / \mathrm{mL}$ were classified as having a deficiency, those with 21-29 $\mathrm{ng} / \mathrm{mL}$ as having an insufficiency, and those with $30 \mathrm{ng} / \mathrm{mL}$ and above as having normal serum vitamin D levels.

Results: The serum 25(OH)D levels of patients in the uncontrolled asthma group, according to the ACT score, were found to be lower than those of patients in the controlled group $(\mathrm{p}=0.002)$. It was determined that as the serum $25(\mathrm{OH}) \mathrm{D}$ levels of the patients increased, the ACT scores also increased significantly $(r=0.280, p=0.001)$. Additionally it was found that each $1 \mathrm{ng} / \mathrm{mL}$ increase in $25(\mathrm{OH}) \mathrm{D}$ level was associated with an increase of $0.176 \mathrm{~L}$ in forced vital capacity (FVC). In addition it was determined that as the serum 25(OH)D levels increased, the patients' $\mathrm{FVCs}$ also increased $(\mathrm{OR}=1.056,95 \% \mathrm{CI}=1.003-1.113, \mathrm{p}=0.038)$. Although the change was not statistically significant $(\mathrm{p}=0.081)$, as serum $25(\mathrm{OH}) \mathrm{D}$ levels increased, the ACT scores also increased.

Conclusion: Vitamin D insufficiency and deficiency were frequently found in adults with asthma and there was a relationship between vitamin D deficiency and pulmonary function. Keywords: Asthma; pulmonary function; vitamin D deficiency.
\end{abstract}

ÖZ

Amaç: $\mathrm{Bu}$ çalışmanın amacı, yetişkin astım hastalarında serum 25-hidroksivitamin D $[25(\mathrm{OH}) \mathrm{D}]$ düzeyleri ile pulmoner fonksiyonlar arasındaki ilişkiyi saptamaktır.

Gereç ve Yöntemler: Toplam 131 astım hastasının genel özellikleri, astım semptomları, solunum fonksiyon testi, astım kontrol testi (AKT) skorları, serum 25(OH)D seviyeleri, vücut ağırlığı ve boy uzunluğu verileri kayıt altına alınmıştır. Hastaların beden kütle indeksleri (BKİ) hesaplanmış ve sınıflandırma için Dünya Sağlık Örgütü kriterleri kullanılmıştır. Serum 25(OH)D seviyesi $20 \mathrm{ng} / \mathrm{mL}$ 'nin altında olan bireyler D vitamini eksikliği, $21-29 \mathrm{ng} / \mathrm{mL}$ olanlar D vitamini yetersizliği ve $30 \mathrm{ng} / \mathrm{mL}$ ve üstü olanlar ise normal serum $\mathrm{D}$ vitamini düzeyi olarak sınıflandırılmıştır.

Bulgular: AKT skoruna göre kontrolsüz astım grubundaki bireylerin serum 25(OH)D düzeyleri, kontrollü gruptaki bireylerden daha düşük bulunmuştur $(p=0,002)$. Bireylerin serum 25(OH)D düzeyleri arttıkça AKT skorlarının da anlamlı şekilde arttığı saptanmıştır ( $\mathrm{r}=0,280$; $\mathrm{p}=0,001)$. Buna ek olarak serum $25(\mathrm{OH}) \mathrm{D}$ seviyesindeki her $1 \mathrm{ng} / \mathrm{mL}$ 'lik artıșın zorlu vital kapasite (forced vital capacity, FVC)'de 0.176 L'lik bir artış ile ilişkili olduğu bulunmuştur. Ayrıca serum 25(OH)D seviyeleri arttıkça, bireylerin FVC düzeylerinin de arttığı tespit edilmiştir (OR=1,056; \%95 GA=1,003-1,113; $\mathrm{p}=0,038)$. İstatistiksel olarak önemli olmamakla birlikte $(\mathrm{p}=0,081)$, serum 25(OH)D seviyeleri arttıkça AKT skorlarının da arttığ belirlenmiştir.

Sonuç: Astım hastası olan yetişkinlerde D vitamini yetersizliği ve eksikliğinin sık görüldüğü ve $\mathrm{D}$ vitamini eksikliği ile solunum fonksiyonu arasında bir ilişki olduğu belirlenmiştir.

Anahtar kelimeler: Astım; pulmoner fonksiyon; D vitamini eksikliği. 


\section{INTRODUCTION}

Asthma is a heterogeneous disease characterized by oversensitivity of the airway and chronic airway inflammation, which develops in response direct or indirect stimuli (1). The World Health Organization (WHO) has reported that 339 million people have asthma worldwide (2). According to WHO estimates, there were 4484.8 deaths (95\% CI: 2414.1-7593.1) due to asthma at the global level in the year 2016 (3). Although the presence of atopy, exposure to environmental allergens and smoking are well known to be important risk factors associated with the onset of asthma, in recent years vitamin D insufficiency has been noticed to be a risk factor for asthma (4).

Vitamin $\mathrm{D}$ is indicated to be much more than a micronutrient. Vitamin D 1,25-dihydroxy, the active metabolite of vitamin $\mathrm{D}\left[1,25(\mathrm{OH})_{2} \mathrm{D}\right]$ is considered to be a hormone, as it is structurally and functionally similar to steroid hormones (4). Studies have shown that vitamin D reduces proinflammatory markers (interleukin-6 and tumour necrosis factor- $\alpha$ ) levels, reduces the antigen delivery of monocyte-macrophage to T cells, prevents the maturation of dendritic cells and shows immunomodulatory effect in addition to the endocrine role as a result of the anti-proliferative effect on lymphocytes $(4,5)$. The effect of vitamin D on the pathogenesis of asthma can also be described as its inhibitory effect on the antigen-providing cells that are essential for the onset and substitution of the cellular immune response. Vitamin D has been shown to inhibit dose-dependent Th1 cells and inflammatory cytokines (such as interleukin-1 alpha-beta, interleukin-12, interferon-gamma), increasing the expression of Th2-dependent cytokines. Vitamin D has also been reported to have anti-proliferative effects on $\mathrm{T}$ cells and to suppress antibody production directly or indirectly in B cells; it also reduces the risk of asthma by activating Treg cells and suppressing peripheral autoreactive $\mathrm{T}$ cells. Due to these properties, vitamin $\mathrm{D}$ is believed to have a role in the reduction of asthma-related morbidity as well as prevention of asthma $(6,7)$. Studies have shown a positive correlation between vitamin D deficiency and severity of asthma in asthma patients, longer hospitalizations and an increased usage of emergency services due to shortness of breath, and a deficiency of vitamin D in asthma patients (811). However, these studies have generally been conducted in the pediatric population, and the studies examining the effect of vitamin D insufficiency on asthma are limited. Therefore, this study was aimed to determine the relationship between serum vitamin $\mathrm{D}$ levels and the pulmonary functions in adult asthma patients.

\section{MATERIAL AND METHODS}

This retrospective study included 131 patients over the age of 18 who had received an asthma diagnosis between 1 March 2019 and 1 June 2019 at the Chest Diseases Polyclinic of the Training and Research Hospital at the University of Health Sciences Antalya. Since serum vitamin D levels may be affected by the time of year, all the patients were selected from patients admitted in the same season (spring). Pregnant, diabetic or cancer patients, vitamin D supplement users and smokers who smoked more than 10 packs/year were not included in the study. The patient examination information filled in by the chest disease specialist was accessed from the hospital information system: age, gender, underlying chronic diseases, smoking status, asthma symptoms, asthma control test (ACT) scores, serum vitamin D and serum IgE levels and body mass indexes (BMIs) [body weight $(\mathrm{kg}) /$ height $(\mathrm{m})^{2}$ ] were calculated. The WHO criteria were used for the classification of BMI (12). Patients with serum 25hydroxyvitamin D [25(OH)D] levels below $20 \mathrm{ng} / \mathrm{mL}$ were classified as having a deficiency, those with 21-29 $\mathrm{ng} / \mathrm{mL}$ as having an insufficiency, and those with 30 $\mathrm{ng} / \mathrm{mL}$ and above as having normal serum vitamin $\mathrm{D}$ levels (13). A Spiro Zan respiratory function test device was used for spirometry evaluations. Forced expiratory volume (FEV1), forced vital capacity (FVC), peak expiratory flow (PEF), forced expiratory volume/forced vital capacity (FEV1/FVC) and forced medium expiratory flow (MEF2575) values were used in the study.

ACT results recorded during the examination were utilized to evaluate the control of asthma-related symptoms. The ACT is a questionnaire that evaluates how well asthma has been controlled, and its Turkish version has been tested for validity and reliability. A score of 20 or more points indicates that the asthma is "controlled" while 19 or fewer points indicates that it is "uncontrolled" (14).

Ethical Committee (Training and Research Hospital, University of Health Sciences Antalya) approval was obtained on 7 November 2019 (Decision no. 24/4).

\section{Statistical Analysis}

The descriptive statistics are presented as frequencies, percentage, mean, standard deviation, median, interquartile range, and minimum-maximum values. The relationships between serum vitamin D levels and ACT scores, respiratory function parameters, serum $\operatorname{IgE}$ and eosinophil levels were evaluated using the Pearson or Spearman correlation test. The patients were divided into tertile according to serum vitamin D levels. The Shapiro-Wilk test was used in the normality test. The Kruskal-Wallis test was used for non-parametric comparison of numerical variables according to the tertiles, and the Dunn Bonferroni post-hoc test was used for significant cases. The ANOVA test was used to compare the tertiles where there was an assumption of normal distribution. The independent effects of vitamin $\mathrm{D}$ on different respiratory function parameters were evaluated using the multiple linear regression model. The effect of insufficient/deficiency vitamin $\mathrm{D}$ level on respiratory function parameters and ACT score was examined by logistic regression analysis. The Hosmer-Lemeshow test was used to test the model's goodness of fit. The SPSS v.22.0 package program was used in all statistical analyses and $\mathrm{p}<0.05$ was considered statistically significant.

\section{RESULTS}

The general characteristics of patients are shown in Table 1. It was determined that the majority of the patients participating in the study $(n=79,60.3 \%)$ were female and approximately half of all patients $(n=56,42.7 \%)$ were between the ages of 18 and $33.92(70.2 \%)$ of the patients had had asthma for 1-5 years and more than half of them did not have any other chronic disease. In patients with chronic diseases, hypertension $(n=24,18.3 \%)$, psychiatric diseases $(n=19,14.5 \%)$ and gastritis/ulcer $(n=10,7.6 \%)$ were the most common diseases. More than half of the 
patients were found to be overweight $(n=49,37.4 \%)$ or obese $(n=31,23.7 \%)$. According to the ACT score, the majority of the patients were in the uncontrolled asthma group $(n=83,63.4 \%)$ and serum vitamin $\mathrm{D}$ levels of $73.3 \%$ $(n=96)$ were deficient $(\leq 20 \mathrm{ng} / \mathrm{mL})$. It was determined that as the serum $25(\mathrm{OH}) \mathrm{D}$ levels of the patients increased, the ACT scores $(p=0.008), F V C(p=0.004)$ and PEF $(p=0.051)$ levels also increased. Although the BMI values of the patients in the first tertile were the highest $(28.1 \pm 5.38$ $\mathrm{kg} / \mathrm{m}^{2}$ ) and those of the patients in the third tertile were the lowest $\left(26.6 \pm 4.81 \mathrm{~kg} / \mathrm{m}^{2}\right)$, this difference was not statistically significant ( $\mathrm{p}=0.291$, Table 2$)$.

Table 3 shows a positive, significant correlation between serum vitamin $D$ level and ACT scores $(\mathrm{r}=0.295, \mathrm{p}=0.001)$, FVC $(\mathrm{r}=0.294, \mathrm{p}=0.001)$, FEV1 $(\mathrm{r}=0.217, \mathrm{p}=0.022)$ and PEF $(r=0.180, p=0.040)$. In the multiple linear regression analysis, it was found that each $1 \mathrm{ng} / \mathrm{mL}$ increase in vitamin D level was associated with an increase of 0.176 units in FVC ( $\mathrm{p}=0.005), 0.158 \mathrm{~L}$ in FEV1 $(\mathrm{p}=0.028)$ and 0.544 point in ACT score $(p=0.024$, Table 4$)$. Table 5 shows the association of the vitamin $\mathrm{D}$ insufficiency with the respiratory function parameters and the ACT score. Accordingly, it was determined that as the serum vitamin D levels increased, the patients' FVCs also increased $(\mathrm{OR}=1.056,95 \% \mathrm{CI}=1.003-1.113, \mathrm{p}=0.038)$. Although the change was not statistically significant $(\mathrm{p}=0.081)$, as serum vitamin D levels increased, the ACT scores also increased.
Table 1. General characteristics of patients, n (\%)

\begin{tabular}{lc}
\hline Sex & \\
Male & $52(39.7)$ \\
Female & $79(60.3)$ \\
Age (year) & \\
$18-33$ & $56(42.7)$ \\
$34-49$ & $41(31.3)$ \\
$50-65$ & $34(26.0)$ \\
Asthma Year & \\
1-5 years & $92(70.2)$ \\
$\geq 6$ years & $39(29.8)$ \\
Asthma treatment & \\
Receiving ICS treatment & $107(81.7)$ \\
Not receiving ICS treatment & $24(18.3)$ \\
Chronic disease status & \\
$\quad$ None & $78(59.5)$ \\
Hypertension & $24(18.3)$ \\
Psychiatric & $19(14.5)$ \\
$\quad$ Gastritis/ulcer & $10(7.6)$ \\
Body mass index $\left(\mathbf{k g} / \mathbf{m}^{2}\right)$ & \\
$\quad$ Normal & $51(38.9)$ \\
Overweight & $49(37.4)$ \\
Obese & $31(23.7)$ \\
Asthma severity & \\
Controlled $(\mathrm{ACT} \geq 20)$ & $48(36.6)$ \\
Uncontrolled $(\mathrm{ACT} \leq 19)$ & $83(63.4)$ \\
Serum 25(OH)D $(\mathbf{n g} / \mathbf{m L})$ & \\
Deficient $(\leq 20 \mathrm{ng} / \mathrm{mL})$ & $96(73.3)$ \\
Insufficient $(20.1-29.9 \mathrm{ng} / \mathrm{mL})$ & $35(26.7)$ \\
\hline ICS: inhaled corticosteroids, ACT: asthma control test, 25(OH)D: 25-hydroxyvitamin D
\end{tabular}

Table 2. The asthma control test score, pulmonary function parameters, IgE, eosinophils and body mass index of patients according to serum vitamin D levels

\begin{tabular}{lcccc}
\hline & Tertile $\mathbf{1}(\mathbf{n}=\mathbf{4 3})$ & Tertile 2 $(\mathbf{n = 4 3})$ & Tertile 3 $(\mathbf{n}=\mathbf{4 5})$ & $\mathbf{p}$ \\
\hline ACT score & $19.5 \pm 2.8$ & $20.9 \pm 3.1$ & $21.5 \pm 2.8$ & 0.008 \\
FVC & $85(19)[57-107]$ & $89(26)[59-125]$ & $94(13)[56-138]$ & 0.004 \\
FEV1 & $82.6 \pm 14.3$ & $87.5 \pm 17.0$ & $89.5 \pm 11.9$ & 0.104 \\
FEV1/FVC & $103.4 \pm 12.9$ & $103.4 \pm 11.1$ & $101.2 \pm 9.3$ & 0.553 \\
PEF & $66.8 \pm 17.9$ & $73.3 \pm 19.9$ & $75.6 \pm 16.4$ & 0.051 \\
MEF2575 & $71.0 \pm 25.5$ & $78.3 \pm 26.5$ & $75.4 \pm 22.6$ & 0.397 \\
IgE & $99(113)[17-694]$ & $110(152)[17-603]$ & $141(130)[17-1660]$ & 0.573 \\
Eosinophils & $200(200)[0-600]$ & $100(200)[0-1000]$ & $200(300)[0-1000]$ & 0.285 \\
BMI $\left(\mathrm{kg} / \mathrm{m}^{2}\right)$ & $28.1 \pm 5.4$ & $26.7 \pm 4.9$ & $26.6 \pm 4.8$ & 0.291 \\
\hline
\end{tabular}

Tertile ranges are as follows: Tertile 1: $\leq 13.89 \mathrm{ng} / \mathrm{mL}$, Tertile $2: 13.9-19.3 \mathrm{ng} / \mathrm{mL}$, Tertile $3: 19.31-29.9 \mathrm{ng} / \mathrm{mL}$, normally distributed variables are presented as mean \pm standard deviation while not-normally distributed variables are presented as median, interquartile range, and minimum-maximum, ACT: asthma control test, FVC: forced vital capacity, FEV1: forced expiratory volume, PEF: peak expiratory flow, MEF2575: forced medium expiratory flow, BMI: body mass index

Table 3. Correlation between serum vitamin D level and asthma control test score, respiratory function parameters, serum IgE, eosinophils and body mass index

\begin{tabular}{lcc}
\hline & $\mathbf{r}$ & $\mathbf{p}$ \\
\hline ACT score & 0.295 & 0.001 \\
FVC & 0.294 & 0.001 \\
FEV1 & 0.217 & 0.022 \\
FEV1/FVC & -0.143 & 0.140 \\
PEF & 0.180 & 0.040 \\
MEF2575 & 0.090 & 0.309 \\
IgE & 0.068 & 0.440 \\
Eosinophils & 0.080 & 0.364 \\
BMI $\left(\mathrm{kg} / \mathrm{m}^{2}\right)$ & -0.109 & 0.217 \\
\hline
\end{tabular}

FVC: forced vital capacity, FEV1: forced expiratory volume, PEF: peak expiratory flow, MEF2575: forced medium expiratory flow, BMI: body mass index
Table 4. Multiple linear regression analysis of the relationship between serum vitamin D levels and pulmonary function parameters

\begin{tabular}{lccccccc}
\hline & B & SE & Beta & t & p & \multicolumn{2}{c}{$95 \%$ CI } \\
\hline Constant & 6.680 & 3.110 & & 2.148 & 0.034 & 0.525 & 12.835 \\
ACT score & 0.544 & 0.239 & 0.275 & 2.278 & 0.024 & 0.071 & 1.016 \\
FVC & 0.176 & 0.062 & 0.432 & 2.844 & 0.005 & 0.053 & 0.298 \\
FEV1 & 0.158 & 0.071 & 0.417 & 2.222 & 0.028 & 0.300 & 0.017 \\
PEF & 0.029 & 0.034 & 0.090 & 0.840 & 0.403 & -0.039 & 0.097
\end{tabular}

$\mathrm{F}=2.403, \mathrm{p}=0.010, \beta$ : coefficient of regression, $\mathrm{SE}$ : standard error, CI: confidence interval, ACT: asthma control test, FVC: forced vital capacity, FEV1: forced expiratory volume, PEF: peak expiratory flow 
Table 5. Logistic regression analysis of the relationship between vitamin D insufficiency and deficiency between pulmonary function parameters and asthma control test score

\begin{tabular}{lcccc}
\hline & OR & \multicolumn{2}{c}{$\mathbf{9 5 \%}$ CI } & p \\
\hline FVC & 1.056 & 1.003 & 1.113 & 0.038 \\
FEV1 & 0.955 & 0.899 & 1.015 & 0.138 \\
PEF & 1.001 & 0.973 & 1.030 & 0.960 \\
ACT score & 1.202 & 0.977 & 1.477 & 0.081 \\
\hline
\end{tabular}

OR: odds ratio, FVC: forced vital capacity, FEV1: forced expiratory volume, PEF peak expiratory flow, ACT: asthma control test

\section{DISCUSSION}

This study found that the prevalence of vitamin D insufficiency in the adult asthmatic population in Turkey (Antalya) was quite high. At the same time, there was a significant relationship between serum vitamin $\mathrm{D}$ level and FVC, FEV1 and PEF.

The prevalence of asthma and the rates of vitamin D insufficiency are increasing worldwide. Vitamin D is thought to have a role in asthma pathogenesis because it has immunomodulatory effects such as improving immune system tolerance and maintaining epithelial barrier integrity (15). In Turkey, vitamin $\mathrm{D}$ deficiency and insufficiency were found in $76.4 \%$ in children with asthma between the ages of $1-4$, and in $90.6 \%$ of children in another similar study $(16,17)$. Although the number of studies of asthmatic adults is quite limited, the prevalence of vitamin D deficiency found in asthma patients in other research is similar to that observed in our study (18-21). In a study conducted on 435 adult asthma patients in China to determine the relationship between serum vitamin $\mathrm{D}$ level and pulmonary function, a significant relationship was found between vitamin D deficiency (50 nmol/L) and FEV1/FVC ratio and FEV1 (18). Similarly, BeyhanSagmen et al. (19) suggested that the FEV1 levels of asthmatic patients with serum vitamin D insufficiency in Turkey were low and that there was a significant linear relationship between vitamin D and FEV1. In one study, every $22.7 \mathrm{~mL}$ increase in FEV1 was found to cause a 1 $\mathrm{ng} / \mathrm{mL}$ increase in serum vitamin D (20). Despite this, 91\% of adult asthmatic patients in Costa Rica had serum vitamin D levels below $30 \mathrm{nmol} / \mathrm{L}$, and although there was a linear relationship between serum vitamin D levels and FEV1, this relationship was not statistically significant (21). In a study involving 760 asthmatic patients in Norway, a significant correlation between serum vitamin D levels and FEV1 was observed only in males because the males participating had a lower level of lung function than the females (22). In this study, it was determined that as the serum vitamin $\mathrm{D}$ levels of the asthma patients increased, the FVC and PEF levels increased, and in multiple linear regression analysis, each $1 \mathrm{ng} / \mathrm{mL}$ increase in vitamin D level was associated with an increase of 0.176 L in FVC, $0.158 \mathrm{~L}$ in FEV1 and 0.544 point in ACT score. Obesity causes the emergence of asthma as a result of its mechanical and inflammatory effects and increases the severity of asthma over time. Patients with a BMI of 35 or more are reported to be approximately twice as much at risk of asthma (23). There is evidence that the active form of vitamin D modulates intracellular ionized calcium signaling in adipocytes, inhibits uncoupling protein-2
(UCP-2), decreases lipolysis, and increases lipogenesis. Accordingly, vitamin D deficiency is thought to play an important role in the development of obesity (24). In our study, more than half of the patients with asthma were found to be overweight $(n=49,37.4 \%)$ or obese $(n=31$, $23.7 \%$ ). In addition, although it was determined that patients' BMIs increased as their serum vitamin D levels decreased, this difference was not found to be statistically significant. Sutherland et al. (20) stated that each unit increase in BMI in adult asthmatic patients caused a decrease in serum vitamin D level of $0.71 \mathrm{ng} / \mathrm{ml}$ and that there was a strong inverse correlation between serum vitamin D levels and BMI, especially in asthmatic patients not receiving inhaled corticosteroid (ICS) therapy. This was associated with higher obesity rates in asthmatic patients not receiving ICS treatment compared to other groups. Despite this, similarly to our study, Li et al. (18) observed lower serum vitamin D levels in asthmatic patients who were obese, but reported that this relationship was not significant. The fact that the sample of our study was small and that more than one-third of the patients had a normal BMI may explain why this relationship was not significant.

The ACT is the most commonly used test today, is easily understood by patients and their families and shows the severity of the asthma (25). It has been stated that there is a relationship between serum vitamin D levels and clinical parameters such as asthma severity, exacerbation, admission to an emergency department and number of hospitalizations $(16,26,27)$. Studies in children have shown that serum vitamin D deficiency exacerbates asthma by 2.6 times (26) and hospital or emergency department admission by 1.5 times (9) compared to the previous year. Few studies have determined the relationship between asthma control and serum vitamin D levels in adults. While there was no relationship between serum vitamin D level and ACT scores in one study, when classified according to serum $25(\mathrm{OH}) \mathrm{D}$ levels, ACT scores were reported to be lower in the group with severe vitamin D deficiency (19). In one study conducted with the elderly, the serum vitamin D levels of patients in the uncontrolled asthmatic group were shown to be lower than those of patients in the controlled group (28). In this study, it was determined that as the serum $25(\mathrm{OH}) \mathrm{D}$ levels of the patients increased, the ACT scores also increased, and that there was a low-level, positive and significant relationship between the ACT scores and serum vitamin D level.

In randomized controlled studies, vitamin D supplements at different doses were found to increase serum $25(\mathrm{OH}) \mathrm{D}$ levels $(29,30)$, decrease exacerbation rates of asthma and increase ACT scores $(28,30,31)$, and positively affect FEV1 $(31,32)$.

However, some limitations should be noted. First, since the study is retrospective, there was no record of the nutrient consumption of patients and the amount of vitamin $\mathrm{D}$ taken in orally could not be calculated. In addition, the patients were not asked about the amount of time they had spent in the sun. Nevertheless, the fact that patients constituting the sample of the study were admitted in the same season (spring) is one of the strengths of the study. Another limitation of the study was the low number of samples and the fact that it was a cross-sectional retrospective study. 


\section{CONCLUSION}

This study tried to explain the role of vitamin D in adult asthma patients. It was determined that vitamin D deficiency was frequently found in adults with asthma and there was a relationship between vitamin D deficiency and pulmonary function. In addition, it was determined that patients with high serum vitamin $\mathrm{D}$ levels have a better asthma course. Since the results of this study are thought to have been affected by factors such as diet, exposure to sun, etc., further studies are recommended that consider multiple factors that may affect the relationship between asthma and vitamin D.

Ethics Committee Approval: The study was approved by the Ethics Committee of Antalya Training and Research Hospital (07.11.2019, 24/4).

Conflict of Interest: None declared by the authors.

Financial Disclosure: None declared by the authors.

Acknowledgements: None declared by the authors.

\section{REFERENCES}

1. Türk Toraks Derneği. Astım Tanı ve Tedavi Rehberi Güncellemesi. Turk Thorac J. 2016;17(Suppl 1):1-96.

2. GBD 2016 Disease and Injury Incidence and Prevalence Collaborators. Global, regional, and national incidence, prevalence, and years lived with disability for 328 diseases and injuries for 195 countries, 1990-2016: a systematic analysis for the Global Burden of Disease Study 2016. Lancet. 2017;390(10100):1211-59.

3. Girum T, Mesfin D, Bedewi J, Shewangizaw M. The burden of noncommunicable diseases in Ethiopia, 2000-2016: analysis of evidence from Global Burden of Disease Study 2016 and Global Health Estimates 2016. Int J Chronic Dis. 2020;2020:3679528.

4. Wöbke TK, Sorg BL, Steinhilber D. Vitamin D in inflammatory diseases. Front Physiol. 2014;5:244.

5. Maalmi H, Berraïes A, Tangour E, Ammar J, Abid H, Hamzaoui K, et al. The impact of vitamin D deficiency on immune $\mathrm{T}$ cells in asthmatic children: a case-control study. J Asthma Allergy. 2012;5:11-9.

6. Hughes DA, Norton R. Vitamin D and respiratory health. Clin Exp Immunol. 2009;158(1):20-5.

7. Paul G, Brehm JM, Alcorn JF, Holguín F, Aujla SJ, Celedón JC. Vitamin D and asthma. Am J Respir Crit Care Med. 2012;185(2):124-32.

8. Ginde AA, Mansbach JM, Camargo CA Jr. Vitamin D, respiratory infections, and asthma. Curr Allergy Asthm R. 2009;9(1):81-7.

9. Brehm JM, Schuemann B, Fuhlbrigge AL, Hollis BW, Strunk RC, Zeiger RS, et al. Serum vitamin D levels and severe asthma exacerbations in the Childhood Asthma Management Program study. J Allergy Clin Immunol. 2010;126(1):52-8.

10. Esfandiar N, Alaei F, Fallah S, Babaie D, Sedghi N. Vitamin D deficiency and its impact on asthma severity in asthmatic children. Ital J Pediatr. 2016;42(1): 108.

11. Korn S, Hübner M, Jung M, Blettner M, Buhl R. Severe and uncontrolled adult asthma is associated with vitamin D insufficiency and deficiency. Respir Res. 2013;14(1):25.
12. Köksal E, Küçükerdönmez Ö. Şişmanlığ1 saptamada güncel yaklaşımlar. In: Baysal $\mathrm{A}$, Baş $\mathrm{M}$, editors. Yetişkinlerde ağırlık yönetimi. İstanbul: Ekspress Bask1; 2008. p.35-70.

13. Holick MF, Binkley NC, Bischoff-Ferrari HA, Gordon CM, Hanley DA, Heaney RP, et al. Evaluation, treatment, and prevention of vitamin D deficiency: an Endocrine Society clinical practice guideline. J Clin Endocrinol Metab. 2011;96(7):1911-30.

14. Uysal MA, Mungan D, Yorgancioglu A, Yildiz F, Akgun M, Gemicioglu B, et al. The validation of the Turkish version of asthma control test. Qual Life Res. 2013;22(7):1773-9.

15. Rajabbik MH, Lotfi T, Alkhaled L, Fares M, El-Hajj Fuleihan G, Mroueh S, et al. Association between low vitamin $\mathrm{D}$ levels and the diagnosis of asthma in children: a systematic review of cohort studies. Allergy Asthma Clin Immunol. 2014;10(1):31.

16. Turkeli A, Ayaz O, Uncu A, Ozhan B, Bas VN, Tufan AK, et al. Effects of vitamin D levels on asthma control and severity in pre-school children. Eur Rev Med Pharmacol Sci. 2016;20(1):26-36.

17. Uysalol M, Mutlu LC, Varol Saracoglu G, Karasu E, Guzel S, Kayaoglu S, et al. Childhood asthma and vitamin D deficiency in Turkey: is there cause and effect relationship between them? Ital J Pediatr. 2013;39:78.

18. Li F, Peng M, Jiang L, Sun Q, Zhang K, Lian F, et al. Vitamin D deficiency is associated with decreased lung function in Chinese adults with asthma. Respiration. 2011;81(6):469-75.

19. Beyhan-Sagmen S, Baykan O, Balcan B, Ceyhan B. Association between severe vitamin D deficiency, lung function and asthma control. Arch Bronconeumol. 2017;53(4):186-91.

20. Sutherland ER, Goleva E, Jackson LP, Stevens AD, Leung DY. Vitamin D levels, lung function, and steroid response in adult asthma. Am J Respir Crit Care Med. 2010;181(7):699-704.

21. Montero-Arias F, Sedó-Mejía G, Ramos-Esquivel A. Vitamin D insufficiency and asthma severity in adults from Costa Rica. Allergy Asthma Immunol Res. 2013;5(5):283-8.

22. Larose TL, Langhammer A, Chen Y, Camargo Jr CA, Romundstad P, Mai XM. Serum 25-hydroxyvitamin D levels and lung function in adults with asthma: the HUNT Study. Eur Respir J. 2015;45(4):1019-26.

23. Özbey Ü, Uçar A. Current factors related with asthma process: obesity and nutrition. GUJHS. 2018;7(2):70-7.

24. Rosen CJ, Adams JS, Bikle DD, Black DM, Demay MB, Manson JE, et al. The nonskeletal effects of vitamin D: an Endocrine Society scientific statement. Endocr Rev. 2012;33(3):456-92.

25. Nathan RA, Sorkness CA, Kosinski M, Schatz M, Li JT, Marcus P, et al. Development of the asthma control test: a survey for assessing asthma control. J Allergy Clin Immunol. 2004;113(1):59-65.

26. Brehm JM, Acosta-Pérez E, Klei L, Roeder K, Barmada M, Boutaoui N, et al. Vitamin D insufficiency and severe asthma exacerbations in Puerto Rican children. Am J Respir Crit Care Med. 2012;186(2):140-6. 
27. Gupta A, Sjoukes A, Richards D, Banya W, Hawrylowicz C, Bush A, et al. Relationship between serum vitamin D, disease severity, and airway remodeling in children with asthma. Am J Respir Crit Care Med. 2011;184(12):1342-9.

28. Columbo M, Panettieri RA Jr, Rohr AS. Asthma in the elderly: a study of the role of vitamin D. Allergy Asthma Clin Immunol. 2014;10(1):1-5.

29. Worth H, Stammen D, Keck E. Therapy of steroidinduced bone loss in adult asthmatics with calcium, vitamin D, and a diphosphonate. Am J Respir Crit Care Med. 1994;150(2):394-7.

30. Martineau AR, MacLaughlin BD, Hooper RL, Barnes
NC, Jolliffe DA, Greiller CL, et al. Double-blind randomised placebo-controlled trial of bolus-dose vitamin D3 supplementation in adults with asthma (ViDiAs). Thorax. 2015;70(5):451-7.

31. Castro M, King TS, Kunselman SJ, Cabana MD, Denlinger L, Holguin F, et al. Effect of vitamin D3 on asthma treatment failures in adults with symptomatic asthma and lower vitamin D levels: the VIDA randomized clinical trial. JAMA. 2014;311(20):2083-91. 32. de Groot JC, van Roon EN, Storm H, Veeger NJ, Zwinderman AH, Hiemstra PS, et al. Vitamin D reduces eosinophilic airway inflammation in nonatopic asthma. J Allergy Clin Immunol. 2015;135(3):670-5. 